Emir. J. Food Agric. 2007. 19 (1): 01-12

http://www.cfa.uaeu.ac.ae/research/ejfa.htm

\title{
Host-plant resistance: A viable non - chemical and environmentally friendly strategy of controlling stored products pests-a review
}

\author{
Ahmed, B. I. $^{1}$ and A. U. Yusuf ${ }^{2}$ \\ ${ }^{1}$ Crop Production Programme, School of Agriculture, Abubakar Tafawa Balewa, \\ University, P. M. B. 0248, Bauchi, Nigeria. ${ }^{2}$ Department of Basic Studies, School of \\ General Studies, Federal Polytechnic, P. M. B. 0231, Bauchi, Nigeria
}

\begin{abstract}
Harvested grains suffer enormous damage from insect pests during storage. Their protection in storage has been the subject of many studies including the search for resistant varieties. Screening of many seed varieties had led to the successful isolation of strains that are resistant to insect pests in some African countries. Amongst grain legumes, three out of the 12,000 cowpea (Vigna unguiculata (L.) Walp.) varieties screened were found to be effectively resistant to two cowpea bruchids (Callosobruchus maculatus F.) and C. subinnotatus (Pic.). Out of 31 Bambara groundnut (Vigna subterranea Thou.) varieties screened, 6 were found to be resistant to these bruchids. Similarly, four varieties of groundnut (Arachis hypogea L.) were found to be resistant to both Indian meal moth (Plodia interpunctella Hubner) and rust red flour beetle (Tribolium castaneum Herbest). Among the cereal grains, 175 maize (Zea mays L.) varieties were investigated and 28 found resistant against both the larger grain borer (Prostephanus truncatus Horn.) and the maize weevil (Sitophilus zeamais Motschulsky). These studies revealed that host-plant resistance is a very good method of combating pest depredation in storage. It is perhaps the easiest, most economical and effective means of controlling insect pests on stored grains as there is no special technology which has to be adopted by farmers. The expenses to the farmer are limited because he only has to buy the seeds and no environmental hazards are involved. Furthermore the method is quite compatible with other methods of control.
\end{abstract}

Keywords: Host-plant resistance, resistant varieties, groundnut, cowpea.

\section{الملفة بين النبلت والعلل : لمترالنيجية قيمة ولبيعية وصصقة للبيئة للقاومة فَلت المخازن - درلسة مرجعية

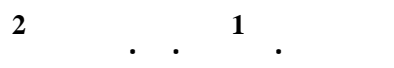

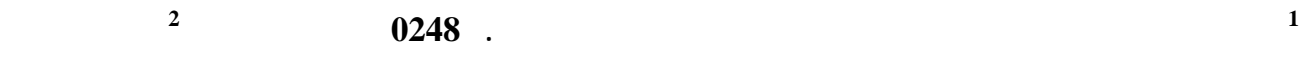

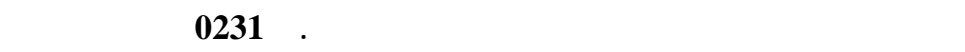

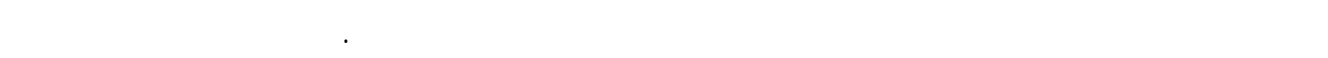

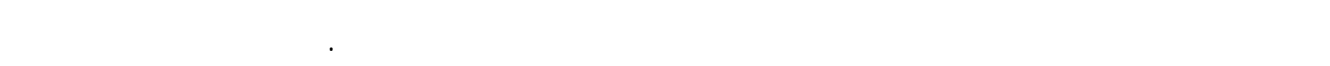

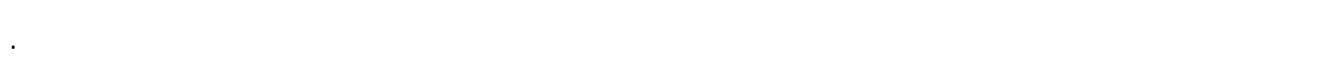

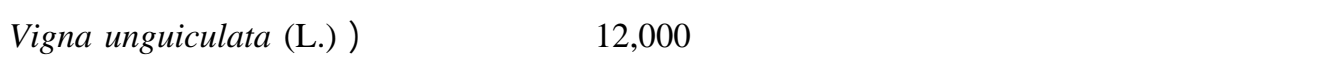
C. Callosobruchus maculates F.) و (Walp. (subinnotatus (Pic.)

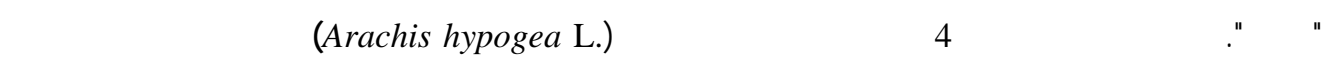

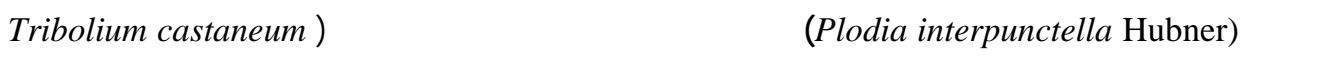
Prostephanus (Hernest

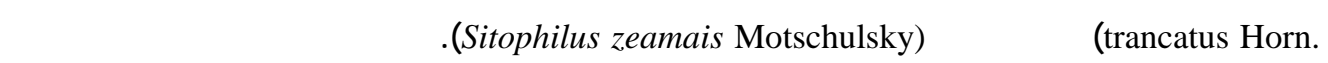

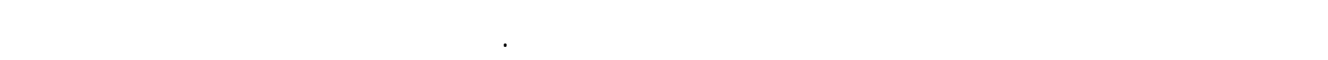




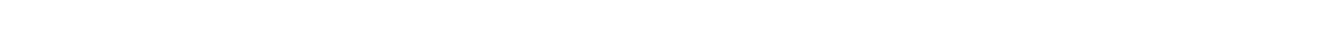

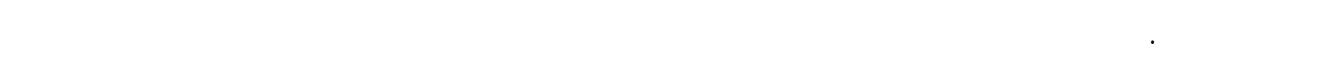

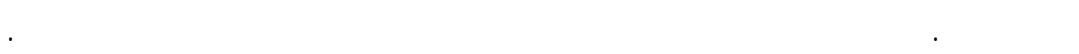

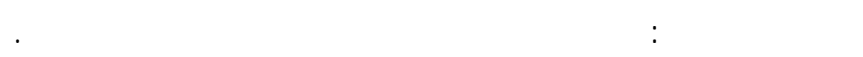

\section{Introduction}

Grain legumes such as cowpea, bambara groundnuts and various forms of beans are important protein sources in the tropics and sub - tropics while cereal grains such as maize and sorghum are important sources of carbohydrates. These crops also serve as sources of income to small-and large-scale farmers in developing countries. Following harvest, these crops are often infested by insect pests in store which cause considerable damage in form of loss of weight, loss and conversion of nutrient, reduction in germination capacity or loss of seed vigour, downgrading and lowering of market value, contamination and aesthetic violation of the grains leading to customer resistance, damage to storage structures and containers, distribution of pathogens and parasites to man and his domestic animals (Ahmed, 2005). Table 1 shows the status of some of the major insect pests of stored agricultural produce in Nigeria. Uncontrolled infestation by these insect pests could lead to total loss of the stored grains as Caswell (1973) reported a 100\% loss in cowpea within $3-5$ months of storage.

Table 2 shows the annual loss estimates in stored legumes for some African countries. These losses range from 8 - 100\%. Caswell (1973) estimated that a $5 \%$ loss of cowpea due to insect infestation costs Nigeria 30 million US dollars per annum. This situation may also be found in some African countries. Similarly, Table 3 shows losses caused to major cereals by insect pests in some African countries. These range from 2 $70 \%$.
The search for viable non-chemical means of controlling stored product pests, especially beetles has been particularly vigorous and significant progress has already been made. This search was necessitated mainly by the harmful side effects and high costs of insecticides and their ability to leave harmful residue in stored produce and of course causing the emergence of resistant strains of pests (Agboola, 1992). For instance Joia et al. (1985) reported that the reduction of residues in flour through bread making with wheat treated with cypermethrin and fenvalerate was slow and that $79-84 \%$ of cypermethrin and $87-88 \%$ of fenvalerate were present in bread made from flour containing residue of both insecticides. This and many other data, which have resulted from the search for alternative pest management strategies, suggest the need for the use of plant varieties with host-resistant qualities in avoiding insect pest infestation in stored produce.

\section{Background Information}

In Africa, non-chemical control programmes have received little or no attention in the past. This may be partly due to a lack of information on the methods, coupled with the absence of trained personnel and research facilities. However, some work have been and are being done on the collection and identification of various predators, parasitoids, disease-causing microorganisms and particularly the screening of insect pest-resistant varieties (Bamaiyi et al., 2000).

Use of resistant varieties is the most cheap, effective and ecologically safe method of protecting grains against insect pests since there is no special technology which has to be adopted by the farmer 
(Helbig, 1997). The expenses to the farmer are limited because he only has to buy the seed and health risks associated with insecticide application are avoided. It is therefore, evident that breeding for resistance to post-harvest pests is important for small and large-scale farmers alike.

\section{Resistance of stored plant materials to insect pests}

Resistance of plant or plant materials to insects is defined as the relative amount of heritable qualities possessed by a plant or its materials (for example, its seeds) which influence the ultimate degree of damage done by the insects (Mbata, 1997). For stored grains, resistance represents the ability of a certain crop variety to produce grains that maintain better quality than commonly cultivated varieties following long storage under similar insect populations (Mbata, 1987).

\section{Mechanism of protection in resistant varieties of grains}

In stored grains several factors lead to the production of resistance against infestation by storage insect pests. These include the tightness of the glumes in unmilled rice (Cogburn and Bollich, 1986; Haryadi and Fleurat-Lassard, 1991) which serve as physical barrier working against penetration by insects; well-fitting and tight-sheating leaves of the husks covering a maize cob (Giles and Ashman, 1971; Kossou et al., 1993) may reduce infestation by Sitophilus spp in the field and in store; hardness of seeds (Jansen, 1977; Dick, 1988) is thought to make insect penetration more difficult thus providing protection; seed size (Nwanze et al., 1975; Dharmasena and Subasinghe, 1986) has also been shown to influence infestation by insect pests as large grain legumes provide more surface area for oviposition and larval development than small-size grains; the texture and hairiness of the coats of cowpea seed; Nwanze et al., 1975; (Nwanze and Horber, 1976; Ofuya and Awelewa, 1993) may have negative influence on the oviposition of the cowpea weevil; the quantity and quality of nutritional constituents (Jackai and Daoust, 1986; Adetunji, 1991; Consoli and Amaral Filho, 1995) have been described to have influence on the fecundity of the females, on the development period of the pre - imaginal instars and on the rate of adult emergence; the presence of compounds which inhibit oviposition and the development of insects on seeds (Gatehouse et al., 1979; Singh et al., 1985; Dobie, 1986; Mbata, 1987; Desroches et al., 1995).

\section{Methods of screening}

Methods for screening resistant grain varieties involve infesting grains artificially with the storage insect under investigation and evaluating the suitability of the test variety for oviposition, duration of development of the insect on the varieties, adult emergence pattern and calculating the susceptibility indices from these observations (Dobie, 1974; Jackai et al., 1985). Losses sustained by the different varieties are compared. Occasionally, particular attention is given in these studies to assessing the effects of relative humidity and the associated variable grain moisture content on pest population dynamics. These parameters have helped in identifying resistant varieties (Mbata, 1986; Mbata et al., 1988; Vowotor et al., 1997).

\section{Varietal resistance in storage grains against insect pests}

The potential of resistant varieties of maize, cowpeas, groundnuts and bambara groundnuts against infestation by insect pests is examined and reviewed.

MaizeSome highly resistant maize varieties and some others with a moderate degree of resistance have been screened against $S$. zeamais which is the 
most important maize storage pest worldwide (Helbig, 1977). Other varieties were also screened for resistance to lepidopteran pests as shown in Table 4. These results show the potentials of some varieties to be adopted by the local farmers against storage insect pests.

Maize is normally stored in three ways: storage of the entire cob with husks intact in open ventilated stores or cribs (Vowotor et al., 1997), as dehusked cob and as shelled grains (Helbig, 1997). Resistance to storage pests in maize has been shown to be strongly affected by the storage form (Vowotor et al., 1994). Furthermore, husk has been shown to give a good protection not only in storage but in the field as well. The fitting of the husk cover, their thickness and hardness have been observed as important factors in protecting the grains against the penetration of insects (Helbig, 1997) and traditional local varieties are usually better protected than the new hybrid ones (Kossou et al., 1993; Helbig, 1997).

Vowotor et al. (1997) screened three maize varieties against population dynamics of Prostephanus truncatus Horn. (Coleoptera: Bostrichidae) and $S$. zeamais in maize stores. The study was divided into long and short season components. Two popular varieties (Abuita and Dzolokpuita) and an improved variety (Abeleechi) were used. Maize cobs were used with their husk intact. The results showed that $P$. truncatus numbers were lower in Dzokpuita than in either Abuita or Abeleechi (Table 5). No significant differences in $S$. zeamais numbers were found with respect to variety as shown in Table 6. Resistance to storage pests has also been observed in maize grains. Srinivas Acharyulus and Chaudhary (1992) screened 84 inbred lines for resistance to $S$. cerealella. They found 11 lines with a high degree of grain resistance to this pest. Cowpea

Many varieties of cowpea screened for resistance against the cowpea bruchid
(C. maculatus) and other Callosobruchus species showed that some varieties posses a very high level of resistance (Table 7). Researchers at the International Institute of Tropical Agriculture (IITA) have screened the entire germplasm collection of cultivated $V$. unguiculata $(12,000$ accessions) and have identified only 3 varieties (TVu 2027, TVu 11952 and $\mathrm{TVu}$ 11953) exhibiting seed resistance to C. maculatus (Singh, 1977). Seck (1993) also reported 6 promising varieties with high resistance out of the 80 varieties screened. Furthermore, Ndolovu and Giga (1988) reported two promising varieties (IT 81D-1032 and IT 81D1064) with high resistance against $C$. rhodesianus out of the 18 varieties screened (Tables 7 and 8).

\section{Groundnuts}

Groundnut is frequently infested with $T$. castaneum and $P$. interpunctella. Results from screening of 22 improved groundnut varieties against these two insect pests revealed 10 promising varieties with high resistance (Mbata, 1986; 1987). Details of which is shown in table 9. The testa, according to Mbata (1995) may have contributed to the resistance in most of the resistant varieties but further explained that the cotyledons may also possess some resistant characteristics due to antibiosis.

\section{Bambara Groundnuts}

Bambara groundnut is known to be infested by both $C$. maculatus and $C$. subinnotatus in storage. Results from screening 21 varieties cultivated in West Africa for resistance against $C$. subinnotatus revealed that three varieties (TVSu 1038, TVSu 346 and TVSu 688) were moderately resistant (Mbata, 1993). Mbata (1992) also reported 3 bambara groundnut varieties (TVSu 119, TVSu 9 and TVSu 11) that showed high resistance against $C$. maculatus out of the ten varieties screened (Table 10). 
Emir. J. Food Agric. 2007. 19 (1): 01-12

http://www.cfa.uaeu.ac.ae/research/ejfa.htm

Table 1. Families, hosts and status of some major insect pests of stored agricultural produce in Nigeria*.

\begin{tabular}{|c|c|c|c|c|}
\hline Family & Common name & Scientific name & Products attacked & Type of pes \\
\hline \multirow[t]{2}{*}{ Bostrychidae } & Lesser grain borer & Rhyzopertha dominica & Cereals & Primary \\
\hline & Larger grain borer & Prostephanus truncatus & Cereals & Primary \\
\hline \multirow[t]{2}{*}{ Bruchidae } & Cowpea bruchid & Callosobruchus maculatus & $\begin{array}{l}\text { Cowpea, bambaranut, } \\
\text { soybean }\end{array}$ & Primary \\
\hline & $\begin{array}{c}\text { Bambara groundnut } \\
\text { bruchid }\end{array}$ & Callosobruchus subinmotatus & Bambara groundnut & Primary \\
\hline \multirow[t]{2}{*}{ Curculionidae } & Rice weevil & Sitophilus oryzae & Cereals & Primary \\
\hline & Maize weevil & Sitophilus zamais & Cereals & Primary \\
\hline Cleridae & Clerid & Necrobia rufipes & $\begin{array}{l}\text { Dried fish \& animal } \\
\text { products }\end{array}$ & - \\
\hline Dermestidae & $\begin{array}{l}\text { Khapra beetle } \\
\text { Skin beetle }\end{array}$ & $\begin{array}{l}\text { Trogoderma granarium } \\
\text { Dermestes maculatus }\end{array}$ & $\begin{array}{l}\text { Oilseeds, cereals } \\
\text { Dried fish \& animal } \\
\text { products }\end{array}$ & Primary \\
\hline Gelechiidae & $\begin{array}{l}\text { Angoumois grain } \\
\text { moth }\end{array}$ & Sitotroga cerealella & Cereals & Primary \\
\hline \multirow[t]{2}{*}{ Pyralidae } & Indian meal moth & Plodia interpunctella & $\begin{array}{l}\text { Cereals,nuts, dried fruits, } \\
\text { farinaceous products }\end{array}$ & Secondary \\
\hline & Rice moth & Corcyra cephalonica & $\begin{array}{l}\text { Cereals \& products, } \\
\text { groundnuts }\end{array}$ & Secondary \\
\hline Tenebrionidae & Flour beetle & Tribolium castaneum & $\begin{array}{l}\text { Cereals \& products, dry } \\
\text { plant material }\end{array}$ & Secondary \\
\hline
\end{tabular}

*Source: Lale (2001)

Table 2. Annual loss estimates of stored grain legumes in some African countries*.

\begin{tabular}{lc}
\hline Country & Percentage losses \\
\hline Cameroun & 10 \\
Ghana & $9-10$ \\
Nigeria & $30-40$ \\
Sierra Leone & 50 \\
South Africa & 5 \\
Uganda & $20-30$ \\
Burkina Faso & $50-100$ \\
\hline
\end{tabular}

*Source: Taylor (1977)

Table 3. Losses caused to major cereal crops by insect pests in some African Counties.

\begin{tabular}{llccc}
\hline $\begin{array}{c}\text { Cereal } \\
\text { Grain }\end{array}$ & \multicolumn{1}{c}{ Insect Species } & Country & $\begin{array}{c}\text { Percentage } \\
\text { Weight loss } \\
\text { estimate }\end{array}$ & Reference \\
\hline Maize & Sitophilus zeamais (Mots.) & Ghana & 20 & Hall, 1970 \\
& Tribolium castaneum (Herbst.) & Uganda & 50 & Hall, 1970 \\
& Sitotroga cerealella (Oliv.) & Kenya & $4-5$ & De Lima, 1979 \\
& Ephestia cautella (W/K) & Nigeria & $5-70$ & Anonymous, 1978 \\
& Prostephanus truncatus (Horn.) & Tanzania & $9-34$ & Hodges, et al., 1983 \\
Wheat & Sitophilus oryzae (L.) & Kenya & 2 & Hall, 1970 \\
& Rhizopertha dominica (F.) & Nigeria & 34 & Hall, 1970 \\
Rice & Sitophilus oryzae (L.) & Sierra- & 10 & Anonymous, 1978 \\
& Sitotroga cerealella (Oliv.) & Leone & 2 & Anonymous, 1978 \\
Millet & Sitophilus oryzae (L.) & Egypt & $2-5$ & Anonymous, 1978 \\
& Sitotroga cerealella (Oliv.) & Mali & 14 & Anonymous, 1978 \\
& & Sudan & & \\
\hline
\end{tabular}


Table 4. Varietal resistance of stored maize to insect pests.

\begin{tabular}{lccc}
\hline Pest - Species & $\begin{array}{c}\text { Number of } \\
\text { Varieties } \\
\text { Screened }\end{array}$ & $\begin{array}{c}\text { Promising } \\
\text { Varieties with } \\
\text { high resistance }\end{array}$ & Reference \\
\hline Sitophilus zeamais & 9 & 4 & IITA 1983 \\
S. zeamais & 16 & 3 & Morah and Mbata, 1986 \\
Sitotroga cerealella & 84 & 11 & $\begin{array}{c}\text { Srinivas Acharyulu \& } \\
\text { Chaudhary, 1992 }\end{array}$ \\
$\begin{array}{l}\text { S. cerealella } \\
\text { Corcyra cephaconica }\end{array}$ & 5 & 1 & $\begin{array}{c}\text { Consoli and Amaral-Filho, } \\
1995\end{array}$ \\
Plodia interpunctella & 13 & 5 & $\begin{array}{c}\text { Mbata, et al., 1988 } \\
\text { Mbata, 1990 }\end{array}$ \\
\hline
\end{tabular}

Table 5. Numbers of Prostephanus truncatus recorded on cobs of three maize varieties stored in "cribs" during the long storage season in Ghana (October 1994 to May, 1995) ${ }^{1}$.

\begin{tabular}{|c|c|c|c|c|}
\hline \multirow[t]{2}{*}{ Sampling } & \multicolumn{3}{|c|}{ Mean number of $P$. truncatus ${ }^{2}$} & \multirow[t]{2}{*}{ F - ratio } \\
\hline & Abuita & Abeleechi & Dzolokpuita & \\
\hline October, 1994 & 0.57 & 00.17 & - & 2.8 \\
\hline November, 1994 & 1.05 & 0.46 & - & 2.45 \\
\hline December, 1994 & $0.93 a$ & - & - & 7.23 \\
\hline January, 1995 & 3.93a & 0.12 & 0.04 & 11.43 \\
\hline February, 1995 & 28.98a & 4.64 & 0.16 & 7.11 \\
\hline March, 1995 & $24.62 \mathrm{a}$ & 5.13 & 1.74 & 7.3 \\
\hline April, 1995 & 109.33a & 15.38 & 6.48 & 5.89 \\
\hline May, 1995 & 131.14a & 3.73 & 16.92 & 10.84 \\
\hline
\end{tabular}

${ }^{1}$ After Vowotor et al. (1997)

${ }^{2}$ Means followed by a letter within a row are significantly different $(\mathrm{p}<0.05)$ (Scheff test) after analysis of variance. Insect numbers determined from 3 pooled 26 - cob samples per crib. Each value is a mean of 4 cribs.

Table 6. Numbers of Sitophilus zeamais recorded on cobs of three maize varieties stored in “cribs” during the long storage season in Ghana (October 1994 to May, 1995) ${ }^{1}$.

\begin{tabular}{lcccc}
\hline Sampling & \multicolumn{3}{c}{ Mean number of } & S. zeamais \\
& Abuita & Abeleechi & Dzolokpuita & F - ratio \\
October, 1994 & & & & \\
November, 1994 & $169.30 \mathrm{a}$ & 81.79 & 69.01 & 17.86 \\
December, 1994 & 232.50 & 259.74 & 212.23 & 0.78 \\
January, 1995 & 281.69 & 349.03 & 348.47 & 1.61 \\
February, 1995 & 217.24 & 297.38 & 251.68 & 1.63 \\
March, 1995 & 242.32 & 263.28 & 213.32 & 0.76 \\
April, 1995 & 226.19 & 243.45 & 242.52 & 0.12 \\
May, 1995 & 255.21 & 277.80 & 231.43 & 0.81 \\
\hline
\end{tabular}

${ }^{1}$ After Vowotor et al. (1997).

${ }^{2}$ Means followed by a letter within a row are significantly different $(\mathrm{p}<0.05)$ (Scheff test) after analysis of variance. Insect numbers determined from 3 pooled 26 - cob samples per crib. Each value is a mean of 4 cribs. 
Emir. J. Food Agric. 2007. 19 (1): 01-12

http://www.cfa.uaeu.ac.ae/research/ejfa.htm

Table 7. Varietal resistance of stored cowpea to insect pests.

\begin{tabular}{lccc}
\hline Pest species & $\begin{array}{c}\text { Number of } \\
\text { varieties } \\
\text { screened }\end{array}$ & $\begin{array}{c}\text { Promising } \\
\text { varieties with } \\
\text { high resistance }\end{array}$ & Reference \\
\hline Callosobruchus maculatus & 12000 & 3 & Singh, 1977 \\
C. maculatus & 27 & 4 & Mbata, 1993 \\
C. maculatus & 80 & 6 & Seck, 1993 \\
C. maculatus & 25 & 3 & Ofuya and Awelewa, 1993 \\
C. maculatus & 13 & 2 & Ofuya and Credland, 1993 \\
C. rhodesianus & 18 & 2 & Ndlovu and Giga, 1988 \\
C. Subinnotatus & 27 & 4 & Mbata, 1993 \\
\hline
\end{tabular}

Table 8. Summary of screening cowpea varieties for resistance to storage insect pests.

\begin{tabular}{|c|c|c|c|}
\hline $\begin{array}{l}\text { No. of varieties } \\
\text { screened }\end{array}$ & $\begin{array}{l}\text { Insect used in } \\
\text { screening }\end{array}$ & $\begin{array}{l}\text { Promising varieties with high } \\
\text { resistance }\end{array}$ & Reference \\
\hline 12000 & $\begin{array}{l}\text { Callosobruchus } \\
\text { maculatus }\end{array}$ & $\begin{array}{c}\text { TVu 2027, TVu 11952, } \\
\text { TVu } 11953\end{array}$ & Singh, 1977 \\
\hline 18 & C. rhodesianus & $\begin{array}{l}\text { IT } 81 D-1032, \\
\text { IT } 81 D-1064\end{array}$ & $\begin{array}{c}\text { Ndlovu and Giga, } \\
1988\end{array}$ \\
\hline $\begin{array}{l}29 \\
29\end{array}$ & C. maculatus & $\begin{array}{l}\text { TVu 2027, IT87D - 1827, } \\
\text { IT84S - 2246 -4, IT81D - } 1007 \\
\text { IT 84S - 2264 - 4, IT 81D - }\end{array}$ & Mbata, 1993 \\
\hline & C. subinnotatus & $\begin{array}{c}\text { 1157, TVu } 2027 \text { (AR), } \\
\text { TVu } 11952 \text { (AR), } \\
\text { TVu } 11953 \text { (AR) } \\
\text { TVu } 310 \text { (AR) }\end{array}$ & Mbata, 1993 \\
\hline
\end{tabular}

Table 9. Summary of screening groundnuts varieties for resistance to pests storage insect.

\begin{tabular}{cccc}
\hline $\begin{array}{c}\text { No. of varieties } \\
\text { screened }\end{array}$ & $\begin{array}{c}\text { Insect used in } \\
\text { screening }\end{array}$ & $\begin{array}{c}\text { Promising varieties with } \\
\text { high resistance }\end{array}$ & Reference \\
\hline 13 & P. interpunctella & M554 - 76, P1274/19, & Mbata, 1987 \\
& & RMP - 12, RMP - 91, & \\
& M 1204 - 781 & \\
& & P1274/191, F452.4, & Mbata, 1986 \\
& T. castaneum & RMP - 12, 2479/79, & \\
& & RMP - 91 & \\
\hline
\end{tabular}


Table 10. Summary of screening bambara groundnuts varieties for resistance to storage insect pests.

\begin{tabular}{cccc}
\hline $\begin{array}{c}\text { Number of varieties } \\
\text { screened }\end{array}$ & Insect used in screening & $\begin{array}{c}\text { Promising varieties with } \\
\text { high resistance }\end{array}$ & Reference \\
\hline 21 & C. subinnotatus & TVSu 1038 & Mbata, 1993 \\
& TVSu 346 & \\
& TVSu 688 & Mbata, 1992 \\
10 & C. maculatus & TVSu 119 & \\
& & TVSu 9 & TVSu 11 \\
\hline
\end{tabular}

\section{Conclusion}

Insect control is essential for storing grains successfully. The control methods may be one of the following: hygienic, physical, chemical, biological or use of resistant crop varieties. Hygienic control measures require good and adequate drying, disinfection and storage practices which are combined with impeccable hygiene that satisfactory results can be achieved (Taylor, 1976). This is only achieved in small- scale farming system. Physical control measures involve modifying the pests' environment in order to make the grain stores more susceptible to control the pests. However, such an approach requires detailed knowledge of the biology of the pests and a clear understanding of the physical characteristics of grain bulks (Allotey, 1991). Chemical control measures is accompanied by inherent risks such as toxic residues contaminating the grains, poisoning of farmers, development of resistance by the insects and pollution of the environment. These chemicals are also beyond the reach of small-scale farmers. An effective chemical used against insect pests in stores must possess the correct blend of biological activity and either low mammalian traits or short residual life. On the other hand, biological control involves the use of natural enemies to suppress the stored grain insects (Benz, 1987). Nevertheless, natural enemies themselves in the grain store are still considered as one of the pollutants, which contaminate stored grains (Allotey, 1991). The use of resistant crop varieties for insect control is based on either antibiosis or antixenosis (Helbig, 1997). In many crops some varieties are less suitable than others for insect development. Such varieties are described as being resistant to insect attack. In small-scale farmers' stores the use of resistant varieties may extend the period during which the produce can be safely stored without the use of pesticides, whereas farmers who grow susceptible varieties may be forced to use expensive chemicals that are difficult to obtain (Dobie, 1984). On the other hand resistant varieties provide a cheep, effective and ecologically safe way of protection of grains against insect pests. The expenses to the farmer are limited because he only has to buy the seed and health risks associated with insecticide application are avoided. From this point of view, breeding for resistance to post-harvest pests is important for small-scale as well as large-scale farmers alike.

\section{References}

Agboola, S. S. 1992. Technologies for small-scale storage of grains in Zaria. In: Zaria, M. B. (ed.) Food storage, processing and utilization. CODRI Occasional Paper No. 1:22-27. 
Adetunji, J. F. 1991. The behavioural responses of Sitophilus oryzae (L.) under conditions modifying the expression of resistance in stored sorghum. In: Fleurat - Lassard and Ducom, P. (Eds). Proceedings of the $5^{\text {th }}$ International Working Conference on stored product protection. Bordeaux, France. 1:15-23.

Ahmed, B. I. 2005. Storage technologies for major crops of Legumes and Cereals. A paper (unpublished) presented at the monthly technology review meeting of the Bauchi State Agricultural

Development Programme, pp15.

Allotey, J. 1991. Storage insect pests of cereal in small-scale farming community and their control. Insect Science and its Application 12:679693.

Anonymous. 1978. Post-harvest food losses in developing countries. National Academy of Science, Washington, D.C., pp206.

Bamaiyi, L. J., M. C. Dike and I. Onu. 2000. Relative susceptibility of some Nigerian sorghum varieties to the rice weevil, Sitophilus oryzae L. Journal of Agricultural Technology 8:26-31.

Benz, G. 1987. Integrated pest management in material protection, storage and food industry. Parasitis 86:31-69.

Caswell, G. H., 1973. The impact of infestation on commodities. Tropical Stored Products Information. 19, p 25.

Cogburn, R.R., and C.N. Bollich. 1986. Host plant resistance to storedproduct insects in varieties and hybrids of rice. In: Donahaye, E. and Navarro, S. (Eds.). Proceedings of the $4^{\text {th }}$ International Working Conference on stored products protection, 1986, Tel - Aviv, Israel. pp504.

Consoli, F. L. and B.K. Amaral-Filho. 1995. Biology of Sitotroga cerealella Olive. (Lepidoptera: Gelechidae) reared on five corn (maize) genotypes. Journal of Stored Products Research 31:139-143.

De Lima, C. P. K. 1979. The assessment of losses due to insects and rodents in maize for subsistence in Kenya. Tropical Stored Products Information 38:21-26.

Desroches, P., E. El-Shazly, N. Mandon, G. Due, and J. Huignard. 1995. Development of Callosobruchus chinensis (L.) and C. maculatus (F.) (Coleoptera: Bruchidae) in seeds of Vicia faba (L.) differing in their tanning, vicine and convicine contents. Journal of Stored Products Research 31:83-89.

Dharmasena, C. M. D. and S. M. C. Subasinghe. 1986. Resistance of mung (Vicia radiata) to Callosobruchus spp. (Coleoptera: Bruchidae). Tropical Agriculture 142:1-6.

Dick, K. 1988. A review of insect infestation of maize in farm storage in Africa with special reference to the ecology and control of Prostephanus truncatus. Overseas Development Authority Natural Resources Institute, Bulletin. No. 18, pp42.

Dobie, P. 1974. The contribution of the tropical stored products centre to the study of insect resistance in stored maize. Tropical Stored products Information 34:7-22.

Dobie, P. 1984. Biological methods for integrated control of insects and mites in tropical stored products 1 . The use of resistant varieties. Tropical Stored Products Information 48:4-8. 
Dobie, P. 1986. Potential uses of host plant resistance. In: Donahage, E. and Navarro, S. (Eds.). Proceedings of the $4^{\text {th }}$ International Working Conference on Stored Products Protection, Tel Aviv, Israel. pp2-13.

Gatehouse, A. M. R., J. A. Gatehouse, P. Dobie, A. M. Kilminster, and D. Boulter. 1979. Biochemical basis of insect resistance in Vigna unguiculata (L.) Walp. Journal of Science and Food Agriculture 30:948-958.

Giles, P. H. and K. Ashman. 1971. A study of Pre-harvest information of maize by Sitophilus zeamais Motsch. (Coleoptera: Curculionidae) in the Kenya Highlands. Journal of Stored Products Research 7:69-83.

Hall, D. W. 1970. Handling and storage of food grains in tropical and subtropical areas. Food and Agriculture Organization Development Paper No. 90, Rome. pp viv +350 .

Haryadi, Y. and F. Fleurat-Lessard. 1991. Relative resistance of different rice varieties against Sitotroga cerealella Olive. (Lepidoptera: Gelechidae). In: Fleurat - Lessard, F. and Ducom, P. (Eds.). Processings of the $5^{\text {th }}$ International Working Conference on Stored Products Protection, Bordeaux, France 1:7986.

Helbig, J. 1997. Host plant resistance to storage insect pests. In: Anonymous (ed.) Integrating biological control and host plant resistance. Proceedings of CTA/IAR/IIBC Seminar. AddisAbaba, Ethiopia, 1995. pp 66-72.

Hodges, R. J., W. R. Dunstan, I. Magazini and P. Golob. 1983. An outbreak of Prostephanus truncatus (Horn.) (Coleoptera: Bostrichidae) in East Africa. Protection Ecology 5:183-194.
IITA ,1983. Research Highlights. pp 4950:68-69.

Jackai, L. E. N. and R. A. Daoust. 1986. Insect pests of cowpeas. Annual Review of Entomology 31:95-119.

Jackai, L. E. N., S. R. Singh, A. K. Raheja and F. Wiedijk. 1985. Recent trends in the control of cowpea pests in Africa. In: Singh, S. R. and Rachie, K. O. (Eds.) Cowpea Research, Production and Utilization. John Wiley and Sons Chichester, U.K. 233-245.

Jansen, D. H. 1977. How southern cowpea weevil larvae, Callosobruchus maculatus (Coleoptera: Bruchidae) die on nonhost seeds. Ecology 58:921-927.

Joia, B. S., G. R .B. Webster and S. R. Loschiaro. 1985. Cypermethrin and Fenvalerate residues in stored wheat and milled fraction. Journal of Agriculture and Food Chemistry 33:618-622.

Kossou, D. K., J. H. Marek and N. A. Bosque-Perez. 1993. Comparison of improved and local maize varieties in the Republic of Benin with emphasis on susceptibility to Sitophilus zeamais Motschulsky. Journal of Stored Products Research 29:333343.

Lale, N. E. S. 2001. The impact of storage insect pests on post-harvest losses and their management in the Nigerian agricultural system. A Symposium paper (unpublished) presented at the $32^{\text {nd }}$ Annual Conference of the Entomological Society of Nigeria, Kaduna. pp17.

Mazarura, U. and D. Giga. 1991. Laboratory and on-farm assessment of resistance to Sitophilus zeamais on maize germplasm. In: FleuratLessard, F. and Ducom, P. (Eds.). 
Proceedings of the $5^{\text {th }}$ International Working Conference on Stored Products Protection. Bordeaux. France 3:1651-1660.

Mbata, G. N. 1986. The susceptibility of varieties of groundnuts to infestation by Tribolium castaneum (Herbst.) (Coleoptera: Tenebrionidae). Tropical Science 26:187-194.

Mbata, G. N. 1987. Studies on the susceptibility of varieties of groundnuts to infestation by Plodia interpunctella (Hb.) (Lepidoptera: Pyralidae). Journal of Stored Products Research 23:57-63.

Mbata, G. N. 1990. Suitability of maize varieties for the oviposition and development of Plodia interpunctella (Hb.) (Lepidoptera: Pyralidae). Management of Tropical Pests 36:122-127.

Mbata, G. N. 1992. The use of resistant crop varieties in the control of storage insects in the tropics and subtropics. Ambio 21:475-478.

Mbata, G. N. 1993. Evaluation of susceptibility of varieties of cowpea to Callosobruchus maculatus (F.) and Callosobruchus subinnotatus (Pic.) (Coleoptera: Bruchidae). Journal of Stored Products Research 2:207213.

Mbata, G. N. 1997. Non-insecticidal protection of stored grain legumes now and in the future. In: Anonymous (ed.). Integrating Biological Control and host plant resistance. Proceedings of a CTA/IAR/IIBC Seminar. AddisAbaba, Ethiopia, 1995. pp 99 - 106.

Mbata, G. N., F. N. C. Osuji and A. N. Okere. 1988. Studies on the developmental biology of Corcyra cephalonica (Stanton) (Lepidoptera: Gelleridae) on thirteen maize varieties. Tropical Science 28:25-34.
Morah, S. C. and G. N. Mbata. 1986. An assessment of relative susceptibility of some maize varieties to postharvest infestation by the maize weevil Sitophilus zeamais (Motsch.). Report of Nigerian Stored Products Research Institute, 1982 Technical Report 5:125-128.

Ndlovu, T. M. and D. P. Giga. 1988. Studies on varietal resistance of cowpea to cowpea weevil, Callasobruchus rhodesianus (Pic.). Insect Science and its Application 9:125-128.

Nwanze, K. F. and E. Horber. 1976. Seed coats of cowpeas affect oviposition and larval development of Callosobruchus maculatus. Environmental Entomology 5:213218.

Nwanze, K. F., E. Horber and C. Pitts. 1975. Evidence of ovipositional preference of Callosobruchus maculatus (F.) for cowpea varieties. Environmental Entomology 4:409412.

Ofuya, T. L. and A. R. Awelewa. 1993. Pod resistance of some cowpea cultivars to the storage beetles, Callosobruchus maculatus Fabricius (Coleoptera: Bruchidae). Journal of Plant Diseases Protection 100:535540.

Ofuya, T. L. and P. F. Credland. 1995. Responses of three populations of the seed beetles, Callosobruchus maculatus (F.) (Coleoptera: Bruchidae) to seed resistance in selected varieties of cowpea, Vigna unguiculata (L.) Walp. Journal of Stored Products Research 31:17-27.

Seck, D. 1993. Resistance to Callasobruchus maculatus F. (Coleoptera: Bruchidae) in some cowpea varieties from Senegal. 
Journal of Stored Products Research 29:49-52.

Singh, S. R. 1977. Cowpea cultivars resistant to insect pests in world germplasm collection. Tropical Grain Legume Bulleting 9:3-7.

Singh, B. B., S. R. Singh and O. Adjadi. 1985. Bruchid resistance in cowpea. Crop Science 25:736-739.

Srinivas Archaryulu, B. S. and R. N. Chaudhary. 1992. Screening of some maize inbred lines to Sitotroga cerealella (Olivier). Indian Journal of Entomology 54:248-254.

Taylor, T. A. 1976. Tropical storage entomology and the small farmer. Proceedings of $\mathrm{XV}$ International Congress on Entomology. Washington, pp673-679.

Taylor, T. A. 1977. Pests and diseases: Studies in the Development of African Resources. Vol. 4, Oxford University Press. pp70.
Vowotor, K. A., B. A. Boateng, J. N. Ayertey, R. D. Oussou, W. G Meikle, C. Borgemeister and R. H. Markham. 1997. Controlling the larger grain borer, Prostephanus truncatus in maize using plant resistance and biological control techniques. In: Anonymous (Ed.). Integrating Biological Control and host plant resistance. Proceedings of a CTA/IAR/IIBC Seminar. AddisAbaba, Ethiopia, 1995. pp219-213.

Vowotor, K. A., N. A. Bosque-Perez and J. N. Ayertey. 1994. Effect of maize variety and storage form on oviposition and development of the maize weevil, Sitophilus zeamais Motschulsky (Coleoptera: Curculionidae). In: E. Highley, E. J. Wright, H. J. Banks and B. R. Champ. (Eds.). Proceedings of the $6^{\text {th }}$ International Working Conference on Stored Products Protection. Canberra, Australia. Vol. I, pp595-598. 